\title{
АКТИВНІСТЬ АЛЬДЕГІДДЕГІДРОГЕНАЗИ ТА ЇЇ МОДУЛЯЦІЯ В СУБКЛІТИННИХ ФРАКЦІЯХ ПЕЧІНКИ ЩУРІВ ПУБЕРТАТНОГО ВІКУ ЗА УМОВ ІММОБІЛІЗАЦІЙНОГО СТРЕСУ
}

\footnotetext{
Метою даного дослідження було вивчення особливостей модуляції активності альдегіддегідрогенази в субклітинних фракціях печінки щурів різного віку, які перебували в умовах тривалої іммобілізації. Встановлено, що формування іммобілізаційного стресу в дорослих статевозрілих тварин не супроводжується зміною альдегіддегідрогеназної активності в субклітинних фракціях печінки. У щурів пубертатного віку (1,5- і 2-місячних тварин) при стресі виникають зміни з боку альдегіддегідрогеназної активності в мітохондріальній і постмітохондріальній фракціях, у результаті чого формуються умови для зниження ролі окиснювального шляху в утилізації ендогенних альдегідів у гепатоцитах.
}

КЛЮЧОВІ СЛОВА: альдегіддегідрогеназа, іммобілізаційний стрес, печінка, пубертат.

ВСТУП. Відомо, що на етапі статевого дозрівання підвищується рівень захворюваності шлунково-кишкового тракту, серцево-судинної, центральної нервової, ендокринної та інших систем організму [3, 4]. Зважаючи на важливу роль стресу в етіології цих захворювань, можна припустити, що однією з причин такого вікового феномена є зниження стійкості тканин внутрішніх органів до дії стресорів у пубертатному віці. На сьогодні в літературі накопичилися численні дані про те, що центральною неспецифічною ланкою стресорного пошкодження внутрішніх органів є стимуляція в них вільнорадикальних процесів [9]. У результаті цього в клітинах накопичуються цитотоксичні карбонільні продукти обміну, які відіграють роль своєрідних месенджерів пошкодження [10]. Найбільш поширеними ендогенними карбонільними сполуками $є$ альдегіди [2]. Захист клітин від альтерації ендогенними альдегідами забезпечується цілою групою ферментів [2, 8], до яких належать і альдегіддегідрогенази (К.Ф. 1.2.1.3 і 1.2.1.4) $[6,7]$. Від їх активності та вмісту залежить стійкість клітин до вільнорадикального пошкодження [1]. Разом із тим, досі все ще відсутні чіткі уявлення про участь альдегіддегідрогеназ в антистресорному захисті, а також про їх значення у віковому зниженні чутливості внутрішніх органів до альтерації при стресі. Враховуючи це, метою даного дослідження було вивчити особливості модуляції (๖ Ю. В. Волкова, л. л. Сухова, В. В. Давидов, 2015. альдегіддегідрогеназної активності в субклітинних фракціях печінки щурів різного віку за умов тривалої іммобілізації.

МЕТОДИ ДОСЛІДЖЕННЯ. Роботу ВИконано на 60 щурах-самцях лінії Вістар чотирьох вікових груп: 1-ша - 1,5-місячні (ранній пубертат); 2-га - 2-місячні (пізній пубертат); 3-тя 3-місячні (рання статева зрілість); 4-та 12-місячні (дорослі статевозрілі). Тварин кожної вікової групи поділили на дві підгрупи: I інтактні; II - щури, які перебували в умовах іммобілізаційного стресу. Для відтворення іммобілізаційного стресу тварин прив'язували до нерухомої опори на 5 год щодня протягом 2 діб.

Евтаназію проводили безпосередньо після припинення іммобілізації шляхом декапітації під легким ефірним наркозом. Видаляли печінку і поміщали її в охолоджений ізотонічний розчин хлористого натрію. Тканину печінки відмивали від крові, подрібнювали ножицями і гомогенізували в скляному гомогенізаторі ПоттераЕльвегейма у співвідношенні 1:10 (маса/об'єм) із розчином, що містив 0,25 М сахарози. Гомогенат фільтрували через 4 шари марлі й центрифугували 10 хв при 1000 g. Супернатант повторно центрифугували 20 хв при $10000 \mathrm{~g}$. Отриману надосадову рідину декантували і використовували як постмітохондріальну фракцію. Осад суспендували з 5 мл середовища виділення і повторно центрифугували протягом 
20 хв при 10000 g. Надосадову рідину видаляли, а утворений осад суспендували з 1,5 мл середовища виділення і використовували в роботі як мітохондріальну фракцію. Усі процедури фракціонування проводили при 4-6 ${ }^{\circ} \mathrm{C}$.

У виділених субклітинних фракціях печінки визначали активність НАД-залежної альдегіддегідрогенази з використанням глутарового альдегіду як субстрату [5]. Концентрацію білка в пробах визначали методом Лоурі.

Статистичну обробку результатів досліджень здійснювали з використанням непараметричного методу Wilcoxon-Mann-Whitney.

РЕЗУЛЬТАТИ Й ОБГОВОРЕННЯ. ПровеДЕН дослідження показали, що альдегіддегідрогеназна активність у постмітохондріальній фракції печінки 1,5-, 2- і 12-місячних щурів істотно не відрізнялась (табл.). У 3-місячних тварин її величина була на $27 \%$ нижчою порівняно з 12-місячними.

У мітохондріальній фракції печінки 3- і 12-місячних щурів альдегіддегідрогеназна активність мала однакову величину (табл.). При цьому в 1,5-місячних тварин вона була на $26 \%$ нижчою, а у 2-місячних - на 127 \% вищою, ніж у 12-місячних щурів.

Після іммобілізації у 3-місячних щурів збільшувалась на 40 \% альдегіддегідрогеназна активність у постмітохондріальній фракції печінки порівняно з її вихідним рівнем. У тварин інших вікових груп іммобілізаційний стрес не супроводжувався зміною величини цього показника.

У мітохондріях печінки альдегіддегідрогеназна активність за умов стресу змінювалась лише у 2-місячних щурів. Після тривалої іммобілізації у них спостерігали ї̈ зниження на 41 \% порівняно з активністю в інтактних тварин даної вікової групи.

Отримані результати вказують на те, що альдегіддегідрогеназна активність у постмітохондріальній фракції печінки щурів пубер- татного віку не відрізнялась від активності в дорослих статевозрілих тварин. Причому величина ферментативної активності в них залишалась незмінною навіть після тривалої іммобілізації. Даний факт може свідчити про те, що в цитозолі гепатоцитів щурів пубертатного віку існували умови для ефективної утилізації карбонільних продуктів вільнорадикального окиснення навіть за підвищення швидкості їх утворення при іммобілізаційному стресі.

На відміну від ферментів постмітохондріальної фракції, активність мітохондріальних альдегіддегідрогеназ печінки змінювалась 3 віком щурів. Базальний рівень альдегіддегідрогеназної активності в мітохондріальній фракції 1,5-місячних тварин був нижчим, ніж у 2- та 12-місячних. За умов стресу величина активності ензиму в 2-місячних щурів стала меншою відносно початкового рівня, а у 1,5-місячних - залишалась на такому ж рівні, як в інтактних тварин даної вікової групи. При цьому в 2-місячних щурів зростала частка немітохондріальних ферментів в альдегіддегідрогеназній активності клітин печінки.

Всебічна оцінка отриманих результатів дозволяє висловити припущення про те, що в щурів пубертатного віку виникають передумови для обмеження катаболізму цитотоксичних продуктів вільнорадикального окиснення в мітохондріях печінки за умов підвищення швидкості їх утворення при стресі. У ранньому пубертатному віці це зумовлено низьким рівнем базальної ферментативної активності в мітохондріях, а у віці пізнього пубертату - їі стресорним зменшенням.

Резюмуючи вищевикладене, можна зробити висновок про те, що формування іммобілізаційного стресу в дорослих статевозрілих тварин не супроводжувалось модуляцією альдегіддегідрогеназної активності в субклітинних фракціях печінки. Водночас у щурів, які перебували на етапі статевого дозрівання, виникали певні метаболічні передумови для

Таблиця - Альдегіддегідрогеназна активність у субклітинних фракціях печінки щурів (нмоль НАДН/мг білка-хв)

\begin{tabular}{|c|c|c|c|c|}
\hline \hline \multirow{2}{*}{$\begin{array}{c}\text { Підгрупа } \\
\text { тварин }\end{array}$} & \multicolumn{4}{|c|}{ Вікова група тварин (міс.) } \\
\cline { 2 - 4 } & 1,5 & 2,0 & 3,0 & 12,0 \\
\hline Постмітохондріальна фракція & $12,4 \pm 0,7$ \\
\hline Інтактні & $11,5 \pm 0,6$ & $9,5 \pm 0,9$ & $9,1 \pm 0,5^{\star}$ & $10,7 \pm 0,1$ \\
\hline Стресовані & $12,2 \pm 0,8$ & $12,2 \pm 1,4$ & $12,8 \pm 1,0^{\star \star}$ & $3,3 \pm 0,2$ \\
\hline \multicolumn{5}{|c|}{ Мітохондріальна фракція } \\
\hline Інтактні & $2,1 \pm 0,2^{\star}$ & $7,5 \pm 0,7^{\star}$ & $4,4 \pm 0,5$ & $2,8 \pm 0,1$ \\
\hline Стресовані & $2,1 \pm 0,3$ & $4,4 \pm 0,7^{\star \star}$ & $6,5 \pm 0,5$ & \\
\hline
\end{tabular}

Примітки. За результатами досліджень на 5-8 тваринах:

1. * - p<0,05 відносно показників 12-місячних тварин.

2. ** $-\mathrm{p}<0,05$ відносно показників інтактних тварин. 
зниження ролі альдегіддегідрогеназного шляху в утилізації карбонільних продуктів вільнорадикального окиснення в мітохондріях і цитозолі гепатоцитів. Виявлені зміни роблять певний внесок у підвищення чутливості печінки до дії пошкоджувальних факторів стресу в пубертатному віці [1]. Причиною виникнення такого феномена можуть бути вікові зміни в структурі ізоферментного спектра альдегіддегідрогеназ у гепатоцитах. У свою чергу, модуляція синтезу певних ізоферментів може бути зумовлена зміною рівня гормональної секреції на етапі статевого дозрівання. Однак дане припущення вимагає спеціальної перевірки. Цьому будуть присвячені наші подальші дослідження.
ВИСНОВКИ. 1. Альдегіддегідрогеназна активність у постмітохондріальній фракції печінки щурів пубертатного віку аналогічна до активності в дорослих статевозрілих тварин. В мітохондріальній фракції печінки 1,5-місячних тварин їі значення нижче, а у 2-місячних - вище, ніж у 12-місячних щурів.

2. Альдегіддегідрогеназна активність у постмітохондріальній фракції печінки щурів пубертатного віку за умов тривалої іммобілізації не змінюється. В мітохондріальній фракції печінки 2-місячних іммобілізованих тварин вона істотно знижується, а в 1,5-місячних - залишається на вихідному рівні.

3. На етапі статевого дозрівання в гепатоцитах щурів виникають умови для зниження ролі окиснювального шляху в утилізації ендогенних альдегідів.

\section{СПИСОК ЛІТЕРАТУРИ}

1. Давыдов В. В. Карбонильный стресс как неспецифический фактор патогенеза / В. В. Давыдов, А. И. Божков // Журн. НАМН Украины. 2014. - 20, № 1. - С. 25-34.

2. Давыдов В. В. Физиологическая и патофизиологическая роль эндогенных альдегидов / В. В. Давыдов, А. И. Божков, О. К. Кульчицкий. Saarbrucken : Palmarium Academic Publishing, 2012. $240 \mathrm{c}$.

3. Коренев М. М. Клініко-гемодинамічні показники формування церебральних порушень у підлітків з первинною артеріальною гіпертензією / М. М. Коренев, О. М. Носова // Педіатрія, акушерство та гінекологія. - 2002. - № 2. - С. 15-18.

4. Коренев Н. М. Артериальная гипертензия у подростков / Н. М. Коренев // Прогнозування та профілактика артеріальної гіпертензії в дитячому та підлітковому віці : збірник доповідей симпозіуму. Харків, 2001. - С. 3-7.

5. Пирожков С. В. Роль альдегиддегидрогеназ в метаболизме малонового диальдегида в печени крыс / С. В. Пирожков, Л. Ф. Панченко // Биохимия. 1988. - 53, № 9. - C. 1443-1448.

6. Aldehyde dehydrogenases and cell proliferation / G. Muzio, M. Maggiora, E. Paiuzzi [et al.] // Free Radic. Biol. Med. - 2012. - 52, № 3. - P. 735-746.

7. Aldehyde dehydrogenases in cellular responses to oxidative/electrophilic stress / S. Singh, C. Brocker, V. Koppaka [et al.] // Free Radic. Biol. Med. - 2013. 56. - P. 89-101.

8. Fritz S. F. An overview of chemistry and biology of reactive aldehydes / S. F. Fritz, D. R. Petersen // Free Radic. Biol. Med. - 2013. - 59, № 2. - P. 85-91.

9. Nayanatara A. K. The effect of repeated swimming stress on organ weights and lipid peroxidation in rats / A. K. Nayanatara, H. S. Nagaraja, B. K. Anupama // Thai J. Physiol. Sci. - 2005. - 18, № 1. P. 3-9.

10. Uchida K. Role of reactive aldehyde in cardiovascular disease / K. Uchida // Free Radical. Biol. Med. - 2000. - 28, № 12. - P. 1685-1696.

ю. В. Волкова, Л. Л. Сухова, В. В. Давыдов ИНСТИТУТ ОХРАНЫ ЗДОРОВЬЯ ДЕТЕЙ И ПОДРОСТКОВ НАМН УКРАИНЫ, ХАРЬКОВ

\section{АКТИВНОСТЬ АЛЬДЕГИДДЕГИДРОГЕНАЗЫ И ЕЕ МОДУЛЯЦИЯ В СУБКЛЕТОЧНЫХ ФРАКЦИЯХ ПЕЧЕНИ КРЫС ПУБЕРТАТНОГО ВОЗРАСТА ПРИ ИММОБИЛИЗАЦИОННОМ СТРЕССЕ}

Резюме

Целью данного исследования явилось изучение особенностей модуляции активности альдегиддегидрогеназы в субклеточных фракциях печени крыс разного возраста, подвергнутых 
продолжительной иммобилизации. Установлено, что формирование иммобилизационного стресса у взрослых половозрелых животных не сопровождается изменением альдегиддегидрогеназной активности в субклеточных фракциях печени. У крыс пубертатного возраста (1,5- и 2-месячных животных) при стрессе возникают изменения со стороны альдегиддегидрогеназной активности в митохондриальной и постмитохондриальной фракциях, в результате чего формируются условия для снижения роли окислительного пути в утилизации эндогенных альдегидов в гепатоцитах.

КЛЮЧЕВЫЕ СЛОВА: альдегиддегидрогеназа, иммобилизационный стресс, печень, пубертат.

Yu. V. Volkova, L. L. Sukhova, V. V. Davydov INSTITUTE OF CHILDREN AND ADOLESCENT HEALTH CARE OF NAMS OF UKRAINE, KHARKIV

\section{ALDEHYDE DEHYDROGENASE ACTIVITY AND ITS MODULATION IN LIVER SUBCELLULAR FRACTIONS OF RATS OF PUBERTAL AGE UNDER CONDITIONS OF IMMOBILIZATION STRESS}

\section{Summary}

The purpose of the present work was to study aldehyde dehydrogenase activity and its modulation in liver subcellular fractions of rats at pubertal age under conditions of immobilization stress. It has been shown that immobilization was accompanied by a change in mitochondrial fraction of liver. In 1.5- monthold rats the enzyme activity was lower than its value in 12- month-old rats, but the activity in 2- month-old rats was higher than the activity in 12- month-old rats. The enzyme activity in liver postmitochondrial fraction of rats at pubertal age was the same as the activity in adult rats. A decrease in aldehyde dehydrogenase activity was accompanied by an increased susceptibility of liver to oxidative stress factors in pubertal age.

KEY WORDS: aldehyde dehydrogenase, immobilization stress, liver, puberty.

Отримано 10.10 .14

Адреса для листування: В. В. Давидов, просп. 50-річчя ВЛКСМ, 52 А, Харків, 61153, Україна, e-mail: vaddavydov@mail.ru. 